\title{
Perceptions of Human Capital Measures: From Corporate Executives and Investors
}

\author{
Lynn L. K. Lim - Christopher C. A. Chan • \\ Peter Dallimore
}

\begin{abstract}
Purpose This study compared the perceptions of executives and investors in terms of the importance to disclose human capital measures and their knowledge of those measures.

Design/methodology/approach Forty-nine senior-level executives ( $41 \%$ response rate) from service-oriented, public-listed companies in Australia and 33 investors (47\% response rate) from various fund management companies responded to our survey.

Findings The investors indicated the importance to disclose certain human capital measures more than the executives. The executives appeared to show a better understanding than the investors on indicators such as staff satisfaction index, staff capacity, motivational index, workforce stability, and workforce competence profile.

Implications To date, researchers have explored human capital from a piecemeal perspective. A more integrated and multifaceted measure of human capital has the potential to benefit fund managers and executives. Disclosure of value added by employees, composition of staff
\end{abstract}

\footnotetext{
L. L. K. Lim

School of Business and Social Sciences, Roehampton

University, Erasmus House, Roehampton Lane,

London SW15 5PU, UK

e-mail: L.Lim@roehampton.ac.uk

C. C. A. Chan $(\varangle)$

Faculty of Liberal Arts \& Professional Studies, School of Human Resource Management, York University, 4700 Keele Street,

Toronto, ON M3J 1P3, Canada

e-mail: cristoph@yorku.ca

P. Dallimore

The University of Notre Dame, Australia, 19 Mouat Street, Fremantle, WA 6959, Australia
}

(full-time, contract, or temporary), staff turnover, average years of experience, and average age of management and operational staff would shed some light on investment decisions for fund managers. Executives could utilize the measures to reflect on an assortment of human capital issues that are relevant to their organizations and stakeholders, especially the investment community.

Originality/value This study proposed a more inclusive measure of human capital by integrating traditional measures of human capital and non-accounting measures (e.g., educational level, experience, and motivation). A comparison of the perspectives of executives and investors revealed preferences for certain information, which can help to improve the perception of transparency and accountability.

Keywords Human capital - Executives' perspective . Investors' perspectives

\section{Introduction}

At the crux of the resource-based view is the belief that human capital provides significant competitive advantage to a firm. The extant literature on human capital suggest that organizations need to recruit, nurture and retain talents so that the knowledge base can be expanded, which has the capacity to improve an organization's overall productivity (Becker 1964; Pfeffer 1994; Boxall 2003; Lin and Wang 2005). This view is based on awareness that knowledge, skills, and expertise are embedded in individuals, who are ultimately responsible for the creation and utilization of knowledge for learning and improvements (Argyris and Schon 1978; Forrester 2000; Lewis et al. 2004). Hence, advocates argue that in order to expand human capital, an 
organization needs to invest in the development of employees and/or attract people with the high knowledge, skills, and expertise from the external labor pool (Snell and Dean 1992; Koch and McGrath 1996).

More recently, some empirical studies have found a positive relationship between human capital and organizational performance. For example, in a study of publiclisted companies in a variety of industries, Youndt and Snell (2004) have found that human capital has significant influences over performance measures such as return on assets and return on equity. In Hayton's (2003) study, practices such as discretionary behavior, knowledge sharing, and organizational learning (arguably these attributes contribute to the building of human capital) significantly affect the entrepreneurial performance of small- and medium-sized enterprises. Discretionary behavior allows organizations to respond to environmental and organizational changes or demands. Such behavior also assists enterprises in entering new markets and creates technologies that are exploited for profit. Thus, these anecdotal and empirical evidences provide impetus for the continuing study of human capital.

As a result of increasing attention placed on human capital, there are keen interests in designing reliable indicators for human capital. There are suggestions that adequate reporting, measuring, and disclosure of human capital indicators need to appear in financial statements (Wintermantel and Mattimore 1997; Chen and Lin 2003). However, such practices are still uncommon as the traditional accounting method has no consistent measure of human capital/asset (Hermanson et al. 1992; Ulrich 1998). Bukowitz et al. (2004) are highly critical of the traditional accounting method, but end up proposing that the human capital metrics should include various cost measures such as wages, separation, sourcing, job vacancy, learning curve, and new hire risks. Owing to the lack of consistent measure of human capital, there exists a fascinating opportunity for researchers and practitioners to develop a more robust system of measuring and reporting human capital information. The development of a robust human capital metrics is likely to provide value for an organization and its stockholders as well as encourage greater private investment (Boudreau and Ramstad 1997; Lewis 1997; Olsson 1999).

Our study extends previous work on human capital in several ways. First, in addition to the use of costs, this study incorporates a variety of non-accounting measures (e.g., educational level of workforce, years of experience, and motivational level). Second, comparisons of senior executives' and fund management investors' perceptions of the importance to disclose the human capital indicators and their knowledge of measuring and monitoring these indicators are conducted. This comparison will provide tremendous value to both groups, as investors can utilize this information to ameliorate their investment decisions and executives can communicate successful human capital investments to the investment community and other stakeholders. Moreover, perception of an organization's competitiveness may improve when there is greater perceived transparency and accountability (Massie 2001). Third, this set of human capital indicators is of great interest to investors and public-listed companies in Australia because there is still limited publicly available information on human capital measurement in the service industry. As more investments shift from the manufacturing sector to the service sector in Australia and in most developed countries (Belasco 1993; OECD 1996; Stewart 1997; Heaton and Oslington 2002), the role played by human resources is ever more important.

In the following section, a framework that includes the key indicators for human capital is presented. Next, explanations of the study design, samples, and measures are described. Finally, the results, limitations, and suggestions for future research are discussed.

\section{Understanding Human Capital}

There is a myriad of definitions for human capital. "Human capital is created by changes in persons that bring about skills, capabilities that make them able to act in new ways" (Coleman 1988, p. S100) It is often defined as the productive capacity imbedded in an individual (Massie 2001). The term also refers to the stock of usable knowledge, skills, capabilities, productivity of an organization and competencies for individuals and for groups that sustain an organization's wealth (Stewart 1995; Galunic and Anderson 2000; Lynn 2000; Sveiby 2001; Lim and Dallimore 2002, 2004; Galbreath 2005). In defining human capital, Malhotra (2000) takes into account the combined knowledge, wisdom, expertise, skill, intuition, innovativeness, and ability of the individuals to meet the tasks and goals at hand, which include values, culture, and philosophy. Other scholars (Davenport 1999; Thorbjornsen and Mouritsen 2003; Van Marrewijk and Timmers 2003) conceptualize human capital as the individual's or firm's collective capability to extract the best solutions from the knowledge of its people, and represents the creativity and innovativeness that exist in each employee's mind to provide solutions to customers. The concept of human capital is also widely used in business literature to develop mechanisms to determine the value of human assets (Elias and Scarbrough 2004). Marti (2001) describes human capital as the generator of all the human intellect and nascent value in a firm's innovativeness. A common thread in these various definitions is that human capital is an advantageous 
resource that is dependent on the collective intelligence of organizational members and the skillful utilization of these resources is likely to improve organizational productivity.

Australian companies do not compare favorably with overseas counterparts, such as companies in Europe, in their ability to manage, develop, support, measure, and report human capital (Petty and Guthrie 1999). However, the government and private sectors recognize the importance of human capital. Besides, intangible resources are of prime importance to companies operating in a postindustrial economy (Galbreath 2005). Given that around $80 \%$ of the companies in Australia are service-based businesses (Watts 2000), there is a need for the industry as a whole to devote adequate resources to develop the human capital to increase Australia's competitiveness globally. In fact, the Australian Department of Industry, Tourism and Resources has stressed that human capital is of fundamental importance to any service industry (Business Queensland 2001). Rupert Murdoch, a global media mogul from Australia, even urges Australia to enter the global competition for human capital, as he believes that this intangible asset will allow Australia to be more competitive on a global scale (Murdoch 2001). Also, the Australian and New Zealand Bank has appointed a Head for its strategic human resources function, People Capital, to oversee the people agenda and building of intellectual capital (ANZ 2001). Additionally, the Australian Accounting Standards Board has further ranked the revaluation of intangible assets such as human capital as one of the highest priority projects (Dixon and Martin 2001), which could abet Australian companies in competing globally for investors.

\section{Perceptions of Human Capital}

Although human capital is recognized as an important asset, the treatment of this asset (in some cases) is incongruent to the belief in practice. Companies in the service industry are operating in an intensely competitive and dynamic environment. In order to remain competitive, the amount and focus of investments in human capital have increased (Bassi and Van Buren 1998). This observation is not surprising because human capital is an important feature in intellectual capital, and the effective management of human capital often creates and sustains an organization's wealth and competitive advantage (Lynn 2000). However, most of the investments in human resource development are recorded as operating expenses (Johanson et al. 1998; Weiss 1998; Guthrie 2001). Yet, personnel is often first to be eliminated when a company decides to downsize and cut cost.

In the late twentieth century, the value creation heavily depended on the creativity of individuals and their knowledge-based human capital (Walsh et al. 2006). Many financial markets are prepared to put very high values on companies that develop their human capital. A probable reason for this decision is that some investors have a longterm orientation because they are confident in investing in businesses with good long-term prospects. Companies known to promote employee values and nurturing of human capital, such as Skandia, have seen financial improvement through human capital investment and reporting (Strassmann 2000). There is also evidence that when it comes to joint ventures, alliances, licensing, or technology sales, the ability to transfer tacit knowledge embodied in the human capital distinguishes successful firms from the less successful ones that merely rely on other commercialization mechanism (Davenport et al. 2002). Thus, having better ways to measure and report human capital information might encourage greater investment, optimize investors' portfolios, and influence the financial performance of an organization (Boudreau and Ramstad 1997; Lewis 1997; Olsson 1999; Ulrich and Smallwood 2005; Chen et al. 2006). Hence, investors are expected to place a higher importance on the disclosure of human capital indicators than executives.

Hypothesis 1 Investors will place a higher importance on the disclosure of human capital indicators than executives.

\section{Knowledge and Awareness of Human Capital} Measurements

The increase in the call for a change in the reporting systems of intangibles or social reporting and provision of supplementary information has seen companies identifying human capital indicators that could influence business and organizational performances. Sveiby (1997) and Sullivan (1998) argue that the managing, measuring, and reporting of intangible asset information are of interest to internal and external audiences who require different knowledge to achieve their goals. As useful information is often needed for decision-making process (O'Loughlin and McFadzean 1999; García-Meca 2005), constructive information to the stockholders or other stakeholders could help them make informed decisions).

External audiences may require information to assess the quality of management and the reliability of organizations as potential business partners, whereas the internal audiences may require the information on operations and progress to determine how their contributions can lead to an increase in the company's business performance. Information that influences stock prices emphatically interests the stockholders. Stockholders expect to receive information from the company that will allow them to better evaluate the company's direction, management, and long-term potential (Sullivan 1998). For example, sudden 
bankruptcies and associated frauds have mounted distrust of corporations. Stockholders who lost millions in the debacles have been putting more pressure on boards of directors to provide greater transparency, accountability, and disclosure of human capital, which would influence judgement on corporate performance. For instance, investors put a value on the former BHP chief executive Paul Anderson when he took over for a short time and investors were prepared to pay a higher price for the Commonwealth Bank of Australia's stocks when the bank was rated as having the highest intellectual assets (Gottlieben 2000).

Thus, the reporting of human capital indicators informs stakeholders the knowledge management activities in an organization (Mouritsen et al. 2001), helps to ameliorate employee morale, and improves understanding of the crucial factors for growth and development (Petty and Guthrie 1999). Failure to value an intangible can undervalue a company (Lev 1999). Consequently, organizations and investors are trying to gain new understandings into the underlying terms, concepts, and complex mechanisms of human capital indicators. Bowen et al. (1997) suggested that a system of indicators could be integrated into stockholder value analysis to provide a long-term profitability perspective. However, much of what has been done to date is for managerial purposes rather than for external reporting (Guthrie 2001). For this reason, executives have a better knowledge of how human capital indicators are measured than investors.

Hypothesis 2 Executives have a better knowledge of how human capital indicators are measured than investors.

\section{Human Capital Indicators}

Albeit the measurement or valuation of human capital is an area of great interest to some academics and practitioners (Vincola and Mobley 1998; Abernathy 1999; Guthrie 2001), there is a lack of agreement as to what should be included in the set of metrics. Economists have traditionally measured the development of human capital in terms of years of education or number of years of experience (OECD 1996). An indicator such as an increase in staff turnover may be seen as a result of staff dissatisfaction and poor business performance. High ratio in turnover and low value retention indicators connote that an organization is not making the proper investment to manage needed knowledge and skills (Vincola and Mobley 1998). A recent study by Sáenz (2005) showed a positive relationship between human capital indicators and the market to book ratio. However, the relationship is absent between human capital indicators and banks' efficiency and financial return.
Several researchers (Edvinsson and Malone 1997; Roos et al. 1997; Bassi and Van Buren 1998; Society of Management Accountants of Canada 1998; Berkowitz 2001; Seleim and Ashour 2004; Sáenz 2005) have proposed various human capital indicators, which are shown in Table 1.

Despite the widespread recognition of the importance of measuring human capital, many investors still do not know what to ask for when it comes to a report of such indicators (Ulrich and Creelman 2006). Our pilot study with a few analysts has revealed that investors and stakeholders acknowledge that some commonly reported indicators have been limited in their function to communicate the value of human capital. As measures are designed to capture the contributing factors in business relationships used to produce a product or service to satisfy the customer, this research may provide an avenue for the investment community and the stakeholders to better evaluate a company's intangible information and for better investment decisions.

\section{Method}

\section{Research Design}

The data collection phase involved three stages. Participants were selected from the public companies listed in the Australian Stock Exchange (ASX). These organizations are from the service sector (excluding trust companies) and from the investment community (i.e., funds management groups). Senior executives (i.e., directors, chief executive offers, and head of division or decision makers) and fund management investors were approached to respond to a survey. Their perceptions and awareness of human capital indicators were solicited.

The focus of this study is on the service industry because the nature of this industry is seen as intellectually or personnel intensive and more homogenous in the structure across services sectors (Mavridis and Kyrmizoglou 2005). The involvement of intangible assets in this sector is critical as companies are dealing with their numerous customers constantly through services. A majority of the Australian investors direct their investment and retirement funds through funds management groups. For this reason, fund management investors would provide valuable contributions to this study. Anderson (1998) and Kalafut and Low (2001) have found that individual and institutional investors (who may be the owner of a company) attributed a significant part of a company's market value to nonfinancial data by taking intangibles into account in their analysis and earnings estimates. As owners of the companies, investors should have the prerogative to determine what information they would like to have disclosed. 
Table 1 Human capital indicators

\begin{tabular}{|c|c|}
\hline Studies & rs and measures \\
\hline $\begin{array}{l}\text { Human focus } \\
\text { indicators } \\
\text { (Edvinsson and } \\
\text { Malone 1997) }\end{array}$ & $\begin{array}{l}\text { Annual turnover of full-time permanent employees } \\
\text { Average age of employees and number with pertinent experience in trade and IT } \\
\text { Average age of full-time or permanent employees } \\
\text { Average years of service with company } \\
\text { Average years with company of full-time or permanent employees } \\
\text { Average years with company of full-time temporary employees } \\
\text { Company managers with advanced degrees: business, science and engineering, liberal arts } \\
\text { Employee turnover } \\
\text { Empowerment index } \\
\text { Full-time or permanent employees who spend less than 50\% of work hours at a corporate facility } \\
\text { IT literacy of staff } \\
\text { Leadership index } \\
\text { Motivation index } \\
\text { Number of directors } \\
\text { Number of employees/employee shares of the company (percent of shares owned by employees, program for employee } \\
\text { buy company shares, etc.) } \\
\text { Number of female directors } \\
\text { Number of female managers } \\
\text { Number of full-time or permanent employees } \\
\text { Number of full-time temporary employees } \\
\text { Number of managers } \\
\text { Number of part-time employees or non-full-time contractors, average duration of contract } \\
\text { Per capita annual cost of training, communication, and support programs for full-time permanent employees } \\
\text { Per capita annual cost of training, communication, and support programs } \\
\text { Per capita annual costs of training and support programs for full-time temporary employees } \\
\text { Percentage of full-time permanent employees } \\
\text { Time in training (days/year) }\end{array}$ \\
\hline $\begin{array}{l}\text { Indicators for } \\
\text { American } \\
\text { Society } \\
\text { for Training \& } \\
\text { Development } \\
\text { (Bassi and Van } \\
\text { Buren 1998) }\end{array}$ & $\begin{array}{l}\text { Retention of key personnel (\% of employees most essential to the organization retained during the previous year) } \\
\text { Ability to attract talented people (\% of openings requiring degrees advanced or substantial experience filled in the previous } \\
\text { year) } \\
\text { IT literacy (\% of employees with a basic level of proficiency in standard office computer applications) } \\
\text { Training expenditures as a percent of payroll (total expenditures on training in the previous year as a percent of the } \\
\text { organization's annual payroll) } \\
\text { Replacement costs of key personnel (average cost to recruit, hire, and train someone to fill an essential job in the organization) } \\
\text { Employee satisfaction (\% of employees highly satisfied with the organization and their jobs) } \\
\text { Employee commitment (\% of employees highly dedicated and committed to the organization) } \\
\text { Organizational learning } \\
\text { Effectiveness of learning transfer in key areas } \\
\text { Management credibility } \\
\text { Employee wages and salaries } \\
\text { Educational levels (\% of college graduates) } \\
\text { Employee empowerment } \\
\text { Management experience } \\
\text { Time in training } \\
\% \text { of employees with } x+\text { years of service } \\
\text { Empowered teams }\end{array}$ \\
\hline
\end{tabular}


Table 1 continued

\begin{tabular}{|c|c|}
\hline Studies & Indicators and measures \\
\hline Roos et al. (1997) & $\begin{array}{l}\text { Average duration of employment } \\
\text { Background variety index (individual and group level) } \\
\text { Company diversification index } \\
\text { Hours of training/employee } \\
\text { Hours spent by senior staff explaining strategy and actions (overlap expertise) } \\
\text { Hours spent in debriefing } \\
\text { IT literacy } \\
\text { Leadership index } \\
\text { Motivation index } \\
\text { New solutions/products/processes suggested } \\
\text { Percent of employees with advanced degrees } \\
\text { Savings from implemented employee suggestions }\end{array}$ \\
\hline $\begin{array}{l}\text { Society of } \\
\text { Management } \\
\text { Accountants of } \\
\text { Canada (1998) }\end{array}$ & $\begin{array}{l}\text { Reputation of company employees with head-hunters } \\
\text { Years of experience in profession } \\
\text { Rookie ratio (percentage of employees with less than } 2 \text { years of experience) } \\
\text { Employee satisfaction } \\
\text { Proportion of employees making new idea suggestions (proportion implemented) } \\
\text { Value added per employee } \\
\text { Value added per salary dollar }\end{array}$ \\
\hline Berkowitz (2001) & $\begin{array}{l}\text { Training dollars in total and per employee } \\
\text { Hours of training in total and per employee } \\
\text { Percent of training to total spending } \\
\text { It investment per employee } \\
\text { Stakeholder satisfaction indicators } \\
\text { Employee satisfaction indicators } \\
\text { Number of employee-generated government owned patents } \\
\text { Revenue per patent } \\
\text { Percent of employees with advanced degrees } \\
\text { Years of experience in the profession } \\
\text { Rookie ratio (percent of employees with less than } 2 \text { years of experience) } \\
\text { Proportion of employees making new ideas and suggestions } \\
\text { Quality performance ratios } \\
\text { Processing time for administrative tasks } \\
\text { Turnover ratios } \\
\text { Value added per employee }\end{array}$ \\
\hline $\begin{array}{l}\text { Seleim and Ashour } \\
\text { (2004) }\end{array}$ & $\begin{array}{l}\text { Number of certified developers } \\
\text { Superstar developers (their performance equals four times the performance of their colleagues) } \\
\text { Star developers (their performance equals two times the performance of their colleagues) } \\
\text { New comers } \\
\text { Leaving developers } \\
\text { Developers who attended project management training programs } \\
\text { Developers who are able to translate customer needs into programming structures } \\
\text { Developers who have the ability to work in a team, training hours for developers } \\
\text { Years of experience } \\
\text { Level of software developer talent }\end{array}$ \\
\hline
\end{tabular}


Table 1 continued

\begin{tabular}{ll}
\hline Studies & Indicators and measures \\
\hline Sáenz (2005) & Average age of staff \\
& Men/women diversity \\
& Percentage of persons with university degree \\
& Percentage of persons promoted out of the total number of staff \\
& Percentage of new recruitments out of the total number of staff \\
& Percentage of persons who are subject to a system of earned income according to objectives \\
& Percentage of persons receiving variable earned income \\
& Percentage of variable earned income in terms of total earned income \\
& Number of hours of training per employee \\
& Percentage of persons trained in terms of the total number of staff \\
\hline
\end{tabular}

Currently, the disclosure of information is usually decided by the accountants, auditors, or management. Although investors may not directly control the release intangible information, they may make executives realized the importance of reporting additional information for investment decision-making purpose. Ultimately, companies need to gain investors' loyalty, which is as important as customers' loyalty. Thus, this research sought to understand the perceptions of the investment community with regard to human capital indicators and how these indicators could assist them in their investment decision-making.

Due to the intricacy of the research, the participants were given considerable time to complete the questionnaire. The survey consisted of three phases, spread over a period of 18 months using an instrument consisting of a structured two-dimensional 5-point Likert scale to determine the importance of disclosing the indicators $(0=$ no comment; $1=$ not important; $2=$ beneficial/useful; 3 = important; and $4=$ very important) and to examine the respondents' level of understanding of how these indicators are being derived or measured $(0=$ no idea; $1=$ somewhat; 2 = average; $3=$ good; and $4=$ very good).

The first phase was designed to obtain expressions of interest from potential participants to contribute in this research. Issues regarding the rationale of the research, the confidentiality, and expected outcomes were mentioned in the request. The second phase involved the mailing of questionnaires to the interested participants. The third phase employed face-to-face unstructured interviews with 12 respondents, who had participated in the survey and expressed their interest to be interviewed, to gain a better understanding of the results. In some instances, the respondents responded to the interview questions by email, as this approach was more convenient. As every business division or function involvement in the reporting and measuring of human capital is critical, prior to submitting the survey, some companies had involved functional and senior executives through board meetings or management meetings. Eventually board members, senior executives, or managers need to be involved in both developing and implementing the new measuring and reporting process.

\section{Sample}

The sample comprised of decision-makers from the publiclisted companies (i.e., executives) and the funds management groups (i.e., investors). These participants were selected from the financial, banking, and telecommunication service sectors listed in the ASX using stratified random sampling. The position level was the key criteria when selecting the participants. The 49 executives (response rate $=41 \%$ ) came from different states in Australia and were based in their head offices. They were directors, heads, or key decision-makers of their organizations. Participants for the funds and investment management group were sampled based on the listing from the Money Management in Australia, an independent weekly journal for the retail financial services industry and an information provider of investment professionals. Most of them are dealing with a handful of funds under an umbrella of investments. In view of the infancy in this research area, some prospective participants were sensitive toward this research and did not take part in this study to avoid being over avant-garde. Nevertheless, 33 (response rate $=47 \%$ ) investors responded to the survey. The majority of the respondents have at least 20 years of experiences in the investment industry. Twenty-six percent (equivalently for both groups) of the respondents voluntarily expressed their interests to a follow-up discussion through qualitative research.

There were many notable characteristics of the sample. More than half of the participants held positions as directors or heads of department, and were above 40 years old. Thirty percent of the participants from the funds 
management groups and half of the participants from the listed service companies had worked in the company for more than 10 years. The average working experience of the executives was about 24 years and about 20 years for those from the funds management group. The average year of experience in their respective industry was 18. Hence, given the seniority, experiences, and influences of the participants, there is confidence that their responses reflect the directions of their firms.

\section{Measures}

Despite the availability of a number of human capital indicators, this research decided to determine a new and more inclusive set of indicators that are relevant to the service industry in Australia. The indicators aim to be measurable, meaningful, inexpensive to collect and process, quantifiable in terms of ratios, percentages and metrics, and more importantly be able to be modified as needed. It is important to keep the end-user in mind when formulating appropriate measurements (Sveiby 1997). Multiple measures are necessary, as no single metric will suffice (Quinn 1994). In order to determine the factors to include in the measures, an exploratory analysis was conducted to extract human capital information disclosed in the annual reports of Australia public companies in the service industry. Interviews with a group of industry analysts assisted in the determination of appropriate human capital indicators. A set of 15 indicators was identified and the descriptions for these indicators are summarized as follows.

\section{Staff Satisfaction Index}

Staff satisfaction plays a crucial role in supporting the achievements of the organization. Staff members who are pleased and contented with the company's management are generally more committed to their work duties. Conversely, when staff members are disgruntled with how the company values them, they may be less dedicated to their work. Staff satisfaction is associated with customer satisfaction, leadership, service processes, and organizational health and sustainability (Burke et al. 2005; Robson et al. 2005). Thus, the productivity of an organization will be affected by staff satisfaction.

\section{Maximization and Utilization of Staff Capacity}

In practice, companies will employ enough employees to service their business operations. The staffing capacity has potential to generate profits. However, some companies may fail to maximize and utilize the total staff capacity, as in the case of over capacity, which would increase the cost for the business. Therefore, measurement and utilization of total staff capacity reveal how well an organization manages its human resource planning.

\section{Ratio of Value Added per Employee}

Value added per employee provides a fundamental measure for labor productivity and efficiency, as a predictor of a company's technological and organizational sophistication, and strongly correlated to profitability (Wiarda and Luria 1998). It also refers to the measure of impact and positive change elicited by training (Abernathy 1999). Several studies on value added per employee have been conducted (Wiarda and Luria 1998; Sesil et al. 2002; Thompson and Heron 2005). An increase in the value added is a measure of the impact of changes to the employee's working environment. Thus, the ratio of value added per employee is useful for comparing with organizations in a similar sector and industry.

Number or Percentage of Full-Time, Part-Time, Contract, or Temporary Staff

The disclosure of the value of staff composition provides an identification of a company's dependence on the nature of staff in the company. According to Edvinsson and Malone (1997), the value of this indicator may point out if the company is carrying too much overhead. A high ratio of contractual or part-time staff could affect the business operation and performance. For example, the use of temporary and contract workers is found to be associated with weak psychological bonds between the internal workforce and the organization (George 2003).

\section{Quarterly, Half-Yearly, and Yearly Staff Turnover}

Mayo (2001) observed the impact of staff turnover could be regarded as asset losses. High staff turnover is a threat to sustained organizational value and some costs. It may result in the loss of organizational knowledge and memory (Seleim and Ashour 2004). Lower staff turnover means less disruption in the functioning of work groups, reduction in stagnation, and improvement innovation (Addison and Belfield 2004; Seleim and Ashour 2004). The cost of recruitment, selection, replacement, and lag time can be enormous.

\section{Average Year of Experience}

An average year of experience is the average collective experience from the first day of their careers. The knowledge retained by individuals is a major strategic resource in 
the business world (Graham and Schwab 1999). Moreover, an organization's ability to assimilate new innovative services depends on its experience (Roberts and Amit 2003). In intellectually demanding professions, a higher average year of experience suggests a high level of cumulative tacit knowledge, which is arguably advantageous in enhancing competitive advantage.

\section{Average Age of Management and Operational Staff}

The average age of management and operational staff aims to observe the management staff leverage and balance. A good mix of expertise and seniority of staff is crucial for a company. A recent trend has seen the retrenchment of staff by many companies affected those who were in their late 40 s or 50 s. Supportive of a good mix of expertise at various age levels, Edvinsson and Malone (1997) have stressed that the conveyance of corporate philosophy is best done by older employees who have been with the same organization for a long time because of their intimate knowledge of corporate history. Sáenz (2005) has suggested that the ideal mix involves a good balance between experience and youth, which purveys contemporary, innovative thoughts, and enables accumulated know-how to be exploited and preserved. Thus, this indicator may have implication to organizational operation and competitiveness in retaining corporate knowledge and experiences.

\section{Average Years of Service with the Company}

The measurement of staff average years of services with a company is in line with staff turnover measurements. The measure is important for determining the knowledge or corporate memory accumulated by the staff in addition to the staff commitment and loyalty to the company.

\section{Average Educational Level of Workforce at Each Functional Level}

The educational level of workforce indicates the basic institutional knowledge of the company and assesses whether there is a need for further education and training of the workforce to respond to industry demands and changes. Training has been shown to be positively related to organizational performance (McLinden et al. 2004). It is reasonable to connote higher average educational level to higher level of human capital asset.

\section{Quarterly, Half-Yearly, and Yearly Turnover of Experts}

Turnover of an expert is considered a more crucial indicator than the general turnover of staff. As Edvinsson and
Malone (1997) have highlighted, the leaving of core personnel poses a great risk to an organization especially when critical knowledge is transferred to a competitor. Thus, a high value on turnover of experts may threaten an organization's human capital value.

\section{Ratio of Men and Women in Management}

The number of men and women in management positions may reflect a company's attitude toward equal employment opportunity. Gender of organization in banking sector has been studied by Benschop and Doorewaard (1998). Organizations with diverse management needs will require different personality types, life experiences, and management styles (Edvinsson and Malone 1997). In Sáenz's (2005) study, a compliance is considered achieved when the percentage of women reaches $50 \%$ of the workforce. However, this indicator should be interpreted based on the context of the similar industry, such as services-related industry. In some industries, more women are in the management teams compared to the traditional domination by men in most industries, such as manufacturing and engineering.

\section{Motivational Index}

Motivation level differs in various hierarchies in an organization. A study by Blunt (1987) concerning the measurement of motivation has shown that subordinates are not consistently reporting high levels of motivation while supervisors differ in their ratings of subordinate motivation. This indicator contributes to a company's success and profitability as well as staff self-concept (Edvinsson and Malone 1997; Shamir 1991). Motivation index of staff is an annual survey that measures the level of staff engagement at work in comparison with the industry or national norms (Barbian 2001). The index determines staff ambition, energy and commitment to the organization, employees' initiatives, and ascertains employee's independence. The indicator also provides companies with a guide to enhance workforce performance levels with training and development.

\section{Workforce Stability}

The workforce stability index measures the duration a staff member stays in a particular position in a company. Job security, procedural fairness and communication, culture, education, personality differences are some key factors of workforce stability (Umiker 1999; Bryson 2003). Workforce stability provides an indication of an organization's competitive edge and potential for survival (Herman 1999; Umiker 1999). The indicator evaluates the stability of relationships; for example, between the customers and the staff 
(Mayo 2001). Also, workforce stability is crucial in managing and decision-making process of human resources activities and operational and functional risks (Bryson 2003). The maintenance of workforce stability is influenced by a conscious and deliberate effort by the entire organization and carefully selecting right staff for the tasks and taking measures to prevent them from abdication and turnover (Herman 1999; Umiker 1999). This indicator also provides information on the average experiences and services of the key players in team projects which are particularly important to companies dealing with longer-term projects.

\section{Workforce Competency Profile}

Knowledge capital comes from competencies and the value of competence has a vital relationship to the commitment of the workforce. Workforce competency profile includes the knowledge, skills and ability of the workforce, and how they relate to the needs of the company. Nothdurft (1990) has related workforce competence on the education and training system with work-relevant curricula and significant work experience of staff in an organization. Competence is usually owned by the employees and leaves the company upon termination of their services with the organizations (Sveiby 1997). Ulrich (1998) has pointed out that the competence level and the commitment level affect the capabilities of talented employees to get things done. Thus, leaders and managers face a challenge in insuring workforce competence as one of organizations' key dimensions and their efforts will increase the profile to compete (Mercer 1998; Kowalski 2003; Li and Benton 2003).

\section{Ratio of Wages or Salary to Total Cost}

The ratio of wages or salary to total cost provides information of the degree of expenses contributed to human resources and should be interpreted in the context of where the company is in the industry. Wages are a cost and a reflection of worth (Bukowitz et al. 2004). Academics and practitioners are recognizing the risk and return of wage or salary in building portfolios and for investors (Chen et al. 2006). For example, the long-term investment, financial portfolios, and dividends for investors could be influenced. As employees are rewarded with respect to the contribution, human resource cost could easily be more than $50 \%$ of an organization's total expenditure.

\section{Results}

Table 2 reports the results of factor analysis of human capital indicators. The exploratory factor analyses established the underlying structure of the inter-relationships among the variables investigated in this research. Using principal components method for extraction, factors with eigenvalues greater than one were retained. Rotations were performed with Varimax technique because of success in obtaining orthogonal rotation of factors for the purposes of other prediction techniques (Hair et al. 1998). The conservative factor loadings of greater than \pm .40 were considered at $95 \%$ level of confidence. Reliability analyses were used to assess the internal consistency of the scales once the dimensionalities of the instruments were verified. The reliability for each construct scale was estimated using Cronbach's alpha coefficient (Cronbach 1951). Items were retained in the scale when the item-to-total correlation was at least .35 , when there was at least five items in the scale, and a coefficient alpha value in the order of .70 was obtained (Nunnally 1967). Overall, the results of factor and reliability analyses demonstrate that the two constructs (i.e., importance to disclose human capital measures and understand the measurement of human capital) have good validities and reliabilities.

Table 3 reports a comparison of the importance to disclose the human capital indicators between executives and investors using $t$-tests. The executive and investor groups had significantly different opinions about the importance of disclosing four human capital indicators. Specifically, the executives thought that disclosing information about the mix of full-time, contract, and temporary staff was significantly more important when compared to the investor group. However, the investors wanted the disclosure of ratio of value added per employee, staff turnover, and average years of experience more than the executive group.

Table 4 reports a comparison of the level of understanding of human capital indicators between the executive and the investors groups. The two groups had different level of understanding for seven human capital indicators. For instance, the executives seemed to understand staff satisfaction, maximization and utilization of staff capacity, motivational index, workforce stability, and workforce competence profile significantly better than the investor group. However, the investors understood average years of experience and average age of management and operational staff compared to the executives.

\section{Discussion}

This research investigated the perceived importance and understanding of human capital measures from the perspectives of executives from the public-listed companies and the investment community. As such, this study will allow companies to better strategize their business by identifying the human capital indicators that contribute to their business performance and competitiveness. 
Table 2 Results of exploratory factor analysis of importance to disclose and understand the measurement of human capital

\begin{tabular}{|c|c|c|c|c|}
\hline \multirow[t]{2}{*}{ Human capital measures } & \multirow[t]{2}{*}{ Mean } & \multirow[t]{2}{*}{ SD } & \multicolumn{2}{|c|}{ Factors } \\
\hline & & & 1 & 2 \\
\hline \multicolumn{5}{|l|}{ Importance to disclose human capital } \\
\hline Staff satisfaction index & 2.57 & 1.08 & .55 & .24 \\
\hline Maximization \& utilization of staff capacity & 2.56 & 1.01 & .56 & .02 \\
\hline Ratio of value added per employee & 2.22 & 1.22 & .61 & .09 \\
\hline Number or percentage of full-time, contract or temporary staff & 2.87 & 1.04 & .33 & .24 \\
\hline Quarterly, half-yearly and yearly staff turnover & 2.65 & 1.16 & .70 & .18 \\
\hline Average years of experience & 2.18 & 1.12 & .76 & -.01 \\
\hline Average age of management and operational staff & 1.66 & 0.96 & .73 & .04 \\
\hline Average years of service with company & 1.79 & 0.95 & .79 & -.04 \\
\hline Average educational level of workforce at each functional level & 2.46 & 1.07 & .64 & .17 \\
\hline Quarterly, half-yearly and yearly expert turnover & 2.39 & 1.21 & .73 & .12 \\
\hline Ratio of men and women in management & 2.26 & 1.08 & .62 & .27 \\
\hline Motivational index & 1.99 & 1.28 & .55 & .16 \\
\hline Workforce stability & 2.16 & 1.20 & .61 & .07 \\
\hline Workforce competence profile & 2.24 & 1.32 & .76 & .02 \\
\hline Ratio of wages or salary to total cost ${ }^{a}$ & 2.51 & 1.24 & .39 & .40 \\
\hline \multicolumn{5}{|l|}{ Understand the measurement of human capital } \\
\hline Staff satisfaction index & 2.49 & 1.19 & -.05 & .67 \\
\hline Maximization \& utilization of staff capacity & 2.37 & 1.08 & -.06 & .61 \\
\hline Ratio of value added per employee & 2.23 & 1.09 & .06 & .49 \\
\hline Number or percentage of full-time, contract, or temporary staff & 3.45 & 0.82 & .18 & .62 \\
\hline Quarterly, half-yearly, and yearly staff turnover & 3.24 & 0.90 & .19 & .69 \\
\hline Average years of experience & 2.91 & 1.04 & .25 & .67 \\
\hline Average age of management and operational staff & 2.82 & 1.23 & .20 & .59 \\
\hline Average years of service with company & 2.96 & 1.13 & .26 & .65 \\
\hline Average educational level of workforce at each functional level & 3.00 & 1.01 & .30 & .62 \\
\hline Quarterly, half-yearly, and yearly expert turnover & 2.74 & 1.12 & .28 & .62 \\
\hline Ratio of men and women in management & 2.82 & 1.10 & .26 & .64 \\
\hline Motivational index & 1.78 & 1.33 & -.07 & .63 \\
\hline Workforce stability & 2.21 & 1.13 & -.04 & .57 \\
\hline Workforce competence profile & 1.93 & 1.23 & -.04 & .65 \\
\hline Ratio of wages or salary to total cost & 3.09 & 1.01 & .21 & .69 \\
\hline Eigenvalues & & & 8.79 & 4.17 \\
\hline Percentage of variance explained & & & 29.31 & 13.91 \\
\hline Cumulative percentage of variance explained & & & 29.31 & 43.22 \\
\hline Cronbach's alpha & & & 0.90 & 0.90 \\
\hline
\end{tabular}

Only factors with eigenvalue $>1$ are retained

$S D$ standard deviation

Bold denotes significant values

a Although this loading is less than .40 , result of reliability analysis shows the removal of this indicator would not improve the alpha value

Recognition of the importance of non-financial measures, value drivers, and how these measures create value for stockholders is growing. Thus, companies should seriously consider the expectations of the investment groups with regard to the disclosure of human capital measures (Stewart 1997). Indisputably, investors' dictation and demands on the importance to disclose human capital indicators could put pressure on executives' view on intangible assets. Human capital indicators can serve as a springboard for organizational growth and development. These indicators can potentially become another tool to gauge executive performance as well as to determine how 
Table 3 Importance to disclose human capital indicators: comparisons between executives and investors

\begin{tabular}{|c|c|c|c|c|}
\hline Human capital indicators & $\begin{array}{l}\text { Executives }(e) \\
n=49\end{array}$ & $\begin{array}{l}\text { Investors }(i) \\
n=33\end{array}$ & $t$-Value & $\begin{array}{l}\text { Mean } \\
\text { comparisons } \\
p<0.05\end{array}$ \\
\hline Staff satisfaction index & $2.69(1.23)$ & $2.39(0.79)$ & 1.347 & N.S. \\
\hline Maximization \& utilization of staff capacity & $2.57(1.15)$ & $2.55(0.75)$ & .123 & N.S. \\
\hline Ratio of value added per employee & $2.00(1.38)$ & $2.55(0.83)$ & -2.225 & $e<i$ \\
\hline Number or percentage of full-time, contract or temporary staff & $3.08(1.10)$ & $2.55(0.87)$ & 2.354 & $e>i$ \\
\hline Quarterly, half-yearly, and yearly staff turnover & $2.41(1.32)$ & $3.00(0.75)$ & -2.578 & $e<i$ \\
\hline Average years of experience & $1.92(1.22)$ & $2.58(0.83)$ & -2.697 & $e<i$ \\
\hline Average age of management and operational staff & $1.57(0.91)$ & $1.79(1.02)$ & -1.003 & N.S. \\
\hline Average years of service with company & $1.67(1.05)$ & $1.97(0.77)$ & -1.474 & N.S. \\
\hline Average educational level of workforce at each functional level & $2.39(1.17)$ & $2.58(0.90)$ & -.780 & N.S. \\
\hline Quarterly, half-yearly, and yearly expert turnover & $2.20(1.27)$ & $2.67(1.08)$ & -1.711 & N.S. \\
\hline Ratio of men and women in management & $2.37(1.17)$ & $2.09(0.91)$ & 1.144 & N.S. \\
\hline Motivational index & $2.02(1.36)$ & $1.94(1.17)$ & .279 & N.S. \\
\hline Workforce stability & $2.08(1.40)$ & $2.27(0.84)$ & -.773 & N.S. \\
\hline Workforce competence profile & $2.37(1.41)$ & $2.06(1.17)$ & 1.070 & N.S. \\
\hline Ratio of wages or salary to total cost & $2.55(1.43)$ & $2.45(0.90)$ & 0.374 & N.S. \\
\hline
\end{tabular}

Table 4 Level of understanding of human capital indicators: comparisons between executives and investors

\begin{tabular}{|c|c|c|c|c|}
\hline Human capital indicators & $\begin{array}{l}\text { Executives }(e) \\
n=49\end{array}$ & $\begin{array}{l}\text { Investors }(i) \\
n=33\end{array}$ & $t$-Value & $\begin{array}{l}\text { Mean comparisons } \\
p<0.05\end{array}$ \\
\hline Staff satisfaction index & $2.90(1.01)$ & $1.88(1.19)$ & 4.175 & $e>i$ \\
\hline Maximization \& utilization of staff capacity & $2.67(1.07)$ & $1.91(0.95)$ & 3.322 & $e>i$ \\
\hline Ratio of value added per employee & $2.16(1.12)$ & $2.33(1.05)$ & -.689 & N.S. \\
\hline Number or percentage of full-time, contract or temporary staff & $3.39(0.86)$ & $3.55(0.75)$ & -.854 & N.S. \\
\hline Quarterly, half-yearly, and yearly staff turnover & $3.14(0.96)$ & $3.39(0.79)$ & -1.248 & N.S. \\
\hline Average years of experience & $2.71(1.04)$ & $3.21(0.99)$ & -2.164 & $e<i$ \\
\hline Average age of management and operational staff & $2.59(1.31)$ & $3.15(1.03)$ & -2.159 & $e<i$ \\
\hline Average years of service with company & $2.84(1.16)$ & $3.15(1.06)$ & -1.244 & N.S. \\
\hline Average educational level of workforce at each functional level & $2.86(1.06)$ & $3.21(0.89)$ & -1.581 & N.S. \\
\hline Quarterly, half-yearly, and yearly expert turnover & $2.78(1.09)$ & $2.70(1.19)$ & .310 & N.S. \\
\hline Ratio of men and women in management & $2.63(1.20)$ & $3.09(0.88)$ & -1.876 & N.S. \\
\hline Motivational index & $2.20(1.34)$ & $1.15(1.06)$ & 3.782 & $e>i$ \\
\hline Workforce stability & $2.43(1.15)$ & $1.88(1.02)$ & 2.211 & $e>i$ \\
\hline Workforce competence profile & $2.33(1.07)$ & $1.33(1.22)$ & 3.904 & $e>i$ \\
\hline Ratio of wages or salary to total cost & $3.08(1.15)$ & $3.09(0.77)$ & -.044 & N.S. \\
\hline
\end{tabular}

key individuals' departure from the organization will affect the companies in short term and long term.

Our study's results reveal that executives and investors have different perspectives on the importance of four human capital indicators. Firstly, although the types of staff composition identify a company's dependence on the types of staff (i.e., full-time, part-time, and temporary), this indicator was perceived to be more important by the executives than the investors. This finding supported the belief that executives were concerned about the company's overhead, which could impact business operation and performance (Edvinsson and Malone 1997). Secondly, the investors felt that it was more important to disclose information about the ratio of value added per employee than the executives. These indicators provide an indication of an organization's productivity, profitability, and innovativeness. Productivity is influenced by a staff's value added in the positive change elicited by training or education, and staff's years of experience and knowledge. The addition revenue generates from added value, staff's experiences, 
and cost of recruiting, and replacing high staff turnover affects the profitability. Staff innovativeness shows a high ratio on value added and helps an organization to stay as a service leader. Thirdly, in terms of staff turnover index, the investors indicated that it was more important to reveal this measure than the executives. A turnover rate in excess of $10 \%$ implies that an organization is not making the proper investment to manage needed knowledge, skills, and behavior (Vincola and Mobley 1998). In contrast, a reduction on staff turnover maintains or improves productivity. Finally, the investors considered that it was more important to disclose information about the average years of experience when compared to the executives. Staff years of experience to the investors also aid in the innovativeness and sophistication of an organization. Hence, these results provide partial support of Hypothesis 1. Our research indicates that there is an argument that exists in viewing the experience and value added. The experience of a person is not the total number of years but should equate to the total times less the time spent on repeat activities. It could equate to the time and productivity spent in a day minus the number of repeats one accumulates.

In terms of the level of understanding of how human capital indicators are measured and processed, our results revealed some interesting findings. Investors demand to know the methodology adopted by a company to determine staff satisfaction index and staff capacity utilization. Currently, different companies have different ways to determine the indicators. This has resulted in some confusion about the methodologies used by organizations to assess human capital. Unexpectedly, the investors have better understanding of the measures of average years of experience and average age of management and operational staff than the executives, which suggests that executives need to consider the reporting of these two measures. Given that motivational level, workforce stability and workforce competence profile indices indicate a firm's ability to compete successfully, executives (who are involved in the daily running of the business) are in a better position to understand the importance of these three measures. Thus, these results provide partial support of Hypothesis 2.

\section{Limitations and Further Research}

The results of this study should be interpreted with the following limitations in mind. First, the cross-sectional nature of the data means that the consistency of the responses of the executives and investors over time cannot be determined. Furthermore, causality cannot be established in this study. Second, given the small sample size, additional statistical analyses may not provide meaningful results. Third, since financial information was not solicited in this study, the linkage between human capital and financial performance cannot be established. Fourth, as this study only investigated the service sector, the results cannot be generalized to the manufacturing sector.

The limitations of this study provide several points of departure for future researchers to extend the field of human capital. For example, future studies could replicate the current study to assess the similarities and differences in responses between the executives and the investors over time. Researchers can also include companies in the manufacturing sector and private companies. An important contribution for future researchers is to establish an empirical link between human capital and financial performance.

Through a follow-up research, some participants have expressed that they would like to see a few more indicators included in future human capital measures. These indicators include executive capital, external hires, executive satisfaction index, and human capital contribution of staff by grade. Executive capital is needed as a separate group to better analyze and understand the links between executive performance and group performance. Information on external hires of the executives or others provides the basis for determining the positive or negative impact on the business. Executive satisfaction index allows staff and customers to feedback across key dimensions of business performance and behavior. A measure on human capital contribution of staff by grade may provide a useful comparison between middle, senior, and executive management levels.

\section{Conclusion}

Human capital is an important facet of strategic human resource management. This idea has important ramifications for financial and information management, business planning, and corporate governance. Human capital continues to be an important feature of innovation, organizational competitiveness, and economic performance. Current corporate annual reports and business reports do a reasonable job in informing stakeholders about the physical assets and financial capital of a company. Yet, they might not necessarily include information about human capital measures. The lack of emphasis on human capital could be due to an unawareness, incomprehension, and intricacy of the indicators. Previous research studies (Edvinsson and Malone 1997; Roos et al. 1997; Bassi and Van Buren 1998; Society of Management Accountants of Canada 1998; Berkowitz 2001) on human capital have not empirically examined the expectations of the producers and users of this information. Hence, a rigorous approach to reporting and measuring 
human capital would require a number of indicators capable of evaluating the intellectual resources of the company.

Companies are encouraged to have the right mix of tangible and intangible assets to compete successfully. Arguably, companies tend to keep their key strategic information secure because they do not want to reveal their competitive advantage. The connection between external parties and an organization is increasingly important. Yet, there is a difference between what internal and external audiences know about companies. The audiences in a company are interested in a range of items of information, whether qualitatively and quantitatively (Sullivan 1998). The audiences of the information include more than just the management and the investors. Users should include various stakeholders such as employees, customers, suppliers, partners, and other collaborators.

Companies may measure human capital indicators for their own use but may be reluctant to publicize it. If efforts are not made to incorporate the value of intangibles into a formalized reporting framework, the management reporting and financial statements will become increasingly irrelevant as a tool to support meaningful decision-making (Guthrie 2001). Companies with strong intellectual assets may be able to attract the attention and retention of their best stakeholders and investors. At the personal level, the human capital of an individual can make a difference in a company and also increase the individual's career advancement.

Acknowledgments We thank the participants who have willingly shared their knowledge and time in this research. We would also like to express our gratitude to the Commonwealth Government of Australia and the University of Notre Dame Australia for making this study possible through their funding. The authors thank the anonymous reviewers for their beneficial feedback.

\section{References}

Abernathy, D. (1999). Thinking outside the evaluation box. Training \& Development, 53, 18-23.

Addison, J. T., \& Belfield, C. R. (2004). What do unions do? Union voice. Journal of Labor Research, 25, 563-596.

Anderson, R. H. (1998). Regulating corporate annual reports in Australia. Business and Economics History, 27, 522-534.

ANZ (2001). Australia and New Zealand Bank appoints head of People Capital. Asian Banker, August 1.

Argyris, C., \& Schon, D. A. (1978). Organizational learning: A theory of action perspective. Reading, MA: Addison-Wesley.

Barbian, J. (2001). How motivated are you? Training \& Development, $38,32$.

Bassi, L. J., \& Van Buren, M. E. (1998). The 1998 ASTD state of the industry report. Training \& Development, 52, 21.

Becker, G. S. (1964). Human capital. New York: Columbia University Press.

Belasco, J. (1993). Leading the new organization. Executive Excellence, 10, 15-16.

Benschop, Y., \& Doorewaard, H. (1998). Covered by equality: The gender subtext of organizations'. Organization Studies, 19, 787-806.
Berkowitz, S. J. (2001). Measuring and reporting human capital Journal of Government Financial Management, 50, 12-17.

Blunt, B. (1987). Employee motivation: Two measurement issues. Review of Public Personnel Administration, 8, 64-68.

Boudreau, J. W., \& Ramstad, P. M. (1997). Measuring intellectual capital: Learning from financial history. Human Resource Management, 36, 343-356.

Bowen, C., Busquet, M., \& Buhner, R. (1997). Increasing shareholder value through human asset management. Long Range Planning, $30,710-717$.

Boxall, P. (2003). HR strategy and competitive advantage in the service sector. Human Resource Management Journal, 13, 5-20.

Bryson, J. (2003). Managing HRM risk in a merger. Employee Relations, 25, 14-30.

Bukowitz, W. R., Williams, R. L., \& Mactas, E. S. (2004). Human capital measurement. Research Technology Management, 47, 43-49.

Burke, R. J., Graham, J., \& Smith, F. (2005). Effects of reengineering on the employee satisfaction-customer satisfaction relationship. The TQM Magazine, 14, 358-363.

Business Queensland (2001, August 17). Products foster business innovation. Business Queensland, 6.

Chen, P., Ibbotson, R. G., Milevsky, M. A., \& Zhu, K. X. (2006). Human capital, asset allocation, and life insurance. Financial Analysts Journal, 62, 97-109.

Chen, H. M., \& Lin, K. J. (2003). The measurement of human capital and its effects on the analysis of financial statements. International Journal of Management, 20, 470-478.

Coleman, J. (1988). Social capital in the creation of human capital. The American Journal of Sociology, 94(Suppl), S95-S120.

Cronbach, L. J. (1951). Coefficient alpha and the internal structure of tests. Psychometrika, 16, 297-334.

Davenport, T. O. (1999). Human capital. Management Review, 88, $37-42$.

Davenport, S., Carr, A., \& Bibby, D. (2002). Leveraging talent: Spinoff strategy at industrial research. $R \& D$ Management, 32, 241254.

Dixon, J., \& Martin, A. (2001). The Australian Accounting Standards Board (AASB) for 2001-2002 (pp. 64-66). Australia: Australian Accountant CPA.

Edvinsson, L., \& Malone, S. (1997). Intellectual capital: Realizing your company's true value by finding its hidden brainpower. New York: Harper Collins.

Elias, J., \& Scarbrough, H. (2004). Evaluating human capital: An exploratory study of management practice. Human Resource Management Journal, 14, 21-40.

Forrester, R. H. (2000). Capturing learning and applying knowledge: An investigation of the use of innovation teams in Japanese and American automotive firms. Journal of Business Research, 47, $35-45$.

Galbreath, J. (2005). The intangible economy and firm superior performance: Evidence from Australia. Journal of the Australian and New Zealand Academy of Management, 11, 28-40.

Galunic, C., \& Anderson, E. (2000). From security to mobility: Generalized investments in human capital and agent commitment. Organization Science, 11, 1-20.

García-Meca, E. (2005). Bridging the gap between disclosure and use of intellectual capital information. Journal of Intellectual Capital, 6, 427-440.

George, R. (2003). External solutions and internal problems: The effects of employment externalization on internal workers' attitudes. Organization Science, 14, 386-402.

Gottlieben, R. (2000). Star power. Shares Magazine, 5, 32.

Graham, A., \& Schwab, D. J. (1999). Boost your magazine's intellectual capital. Folio: The Magazine for Magazine Management, 28, 27. 
Guthrie, J. (2001). The management, measurement and the reporting of intellectual capital. Journal of Intellectual Capital, 2, 27-41.

Hair, J. F. J., Anderson, R. E., Tatham, R. L., \& Black, W. C. (1998). Multivariate data analysis. Upper Saddle River, NJ: Prentice-Hall.

Hayton, J. C. (2003). Strategic human capital management in SMEs: An empirical study of entrepreneurial performance. Human Resource Management Journal, 42, 375-391.

Heaton, C., \& Oslington, P. (2002). The contribution of structural shocks to Australian unemployment. Economic Record, 78, 433442.

Herman, R. E. (1999). Stability is watchword for effective workforce. HR Focus, June, S1-S3.

Hermanson, D. R., Hermanson, R. H., \& Ivancevich, D. M. (1992). Human resource accounting in a recessionary times. Management Accounting, 74, 69.

Johanson, U., Eklöv, G., Holmgren, M., \& Mårtensson, M. (1998). Human resource costing and accounting versus the balanced scorecard. OECD Report. Stockholm: School of Business, Stockholm University.

Kalafut, P. C., \& Low, J. (2001). The value creation index: Quantifying intangible value. Strategy and Leadership, 29, 9-15.

Koch, M. J., \& McGrath, R. G. (1996). Improving labor productivity: Human resource management policies do matter. Strategic Management Journal, 17, 335-354.

Kowalski, B. (2003). The engagement gap. Training \& Development, 40,62 .

Lev, B. (1999). The inadequate public information on intellectual capital and its consequences. International symposium measuring and reporting intellectual capital: Experiences, issues, and prospects. OECD, Amsterdam.

Lewis, G. (1997). Building intellectual capital. Management Accounting, 75, 54.

Lewis, J., Wright, P. C., \& Geroy, G. D. (2004). Managing human capital: The study of a self-managed group venturing into the digital economy. Management Decision, 42, 205-228.

Li, L., \& Benton, W. C. (2003). Hospital capacity management decisions: Emphasis on cost control and quality enhancement. European Journal of Operational Research, 146, 596-614.

Lim, L. L. K., \& Dallimore, P. (2002). To the public-listed companies, from the investment community. Journal of Intellectual Capital, Special Issue, 3, 262-276.

Lim, L. L. K., \& Dallimore, P. (2004). Intellectual capital: Management attitudes in service industries'. Journal of Intellectual Capital, 5, 181-194.

Lin, K. J., \& Wang, M. L. (2005). The classification of human capital according to the strategic goals of firms: An analysis. International Journal of Management, 22, 62-70.

Lynn, B. E. (2000). Intellectual capital. Ivey Business Journal, 64, $48-51$.

Malhotra, Y. (2000). Knowledge assets in the global economy: Assessment of national intellectual capital. Journal of Global Information Management, 8, 5-15.

Marti, J. M. V. (2001). ICBS-Intellectual capital benchmarking system. Journal of Intellectual Capital, 2, 148-165.

Massie, R. K. (2001, July 1). Reporting on sustainability: A global initiative. OECD Observer, 60 .

Mavridis, D. G., \& Kyrmizoglou, P. (2005). Intellectual capital performance drivers in the Greek banking sector. Management Research News, 28, 43-62.

Mayo, A. (2001). Memory bankers. People Management, 4, 345.

McLinden, D., Casper, W. J., \& Kraiger, K. (2004). Contributions of psychological research to HRM: Collaborative planning for training impact. Human Resource Management Journal, 43, $337-352$.
Mercer, G. (1998). Operational improvements: How to build cars more effectively. Part 1. Automotive Manufacturing \& Production, 110, 74-76.

Mouritsen, J., Larsen, H. T., \& Bukh, P. N. (2001). Valuing the future: Intellectual capital supplements at Skandia. Accounting, Auditing and Accountability Journal, 14, 399-422.

Murdoch, R. (2001). The human wealth of nations. Speech at Keith Murdoch Memorial Oration, Melbourne, Australia.

Nothdurft, W. E. (1990). How to produce work-ready workers. Across the Board, 27, 47-52.

Nunnally, J. C. (1967). Psychometric theory. New York: McGrawHill.

O'Loughlin, A., \& McFadzean, E. (1999). Toward a holistic theory of strategic problem solving. Team Performance Management, 5 , 103-120.

OECD. (1996). The knowledge-based economy. Retrieved 12 November 1998, from http://www.oecd.org/dsti/sti/s_t/inte/prod/ kbe.htm

Olsson, B. (1999). The construction of transparency through accounting on intellectual capital? Journal of Human Resource Costing and Accounting, 4, 7-10.

Petty, R., \& Guthrie, J. (1999). Managing intellectual capital: From theory to practice. Australian Accountant, August 1, 8-21.

Pfeffer, J. (1994). Competitive advantage through people: Unleashing the power of the workforce. Boston: Harvard Business School Press.

Quinn, J. B. (1994). Appraising intellectual assets. The McKinsey Quarterly, March 22, 90-95.

Roberts, P. W., \& Amit, R. (2003). The dynamics of innovative activity and competitive advantage: The case of Australian retail banking. Organization Science, 14, 107-122.

Robson, A., Yarrow, D., \& Owen, J. (2005). Does quality drive employee satisfaction in the UK learning sector? The International Journal of Quality and Reliability Management, 22, 465-484.

Roos, J., Roos, G., Dragonetti, N. C., \& Edvinsson, L. (1997). Intellectual capital: Navigating in the new business landscape. London: MacMillan Business.

Sáenz, J. (2005). Human capital indicators, business performance and market-to-book ratio. Journal of Intellectual Capital, 6, 374-384.

Seleim, A., \& Ashour, A. (2004). Intellectual capital in Egyptian software firms. The Learning Organization, 11, 332-346.

Sesil, J. C., Kroumova, M. K., Blasi, J. R., \& Kruse, D. L. (2002). Broad-based employee stock options in US 'New economy' firms. British Journal of Industrial Relations, 40, 273-294.

Shamir, B. (1991). Meaning, self and motivation in organizations. Organization Studies, 12, 405-426.

Snell, S. A., \& Dean, J. W. (1992). Integrated manufacturing and human resource management: A human capital perspective. Academy of Management Journal, 35, 467-504.

Society of Management Accountants of Canada. (1998). The management of intellectual capital: The issues and the practice. Issues Paper no. 16. The Society of Management Accountants of Canada, Hamilton.

Stewart, T. (1995). Getting real about brainpower. Fortune, 27, 201203.

Stewart, T. (1997). Intellectual capital: The new wealth of organizations. London: Nicholas Brealey.

Strassmann, P. A. (2000). Intelligence in question. Knowledge Management, 3, 16

Sullivan, P. H. (1998). Profiting from intellectual capital-Extracting value from innovation. New York: Wiley.

Sveiby, K. E. (1997). The new organizational wealth: Managing and measuring knowledge-based assets. San Francisco: BarrettKoehler. 
Sveiby, K. E. (2001). A knowledge-based theory of the firm to guide in strategy formulation. Journal of Intellectual Capital, 2, 344-358.

Thompson, M., \& Heron, P. (2005). Management capability and high performance work organization. International Journal of Human Resource Management, 16, 1029-1048.

Thorbjornsen, S., \& Mouritsen, J. (2003). Accounting for the employee in the intellectual capital statement. Journal of Intellectual Capital, 4, 559-575.

Ulrich, D. (1998). Intellectual capital = competence $\times$ commitment Sloan Management Review, 39, 15-26.

Ulrich, D., \& Creelman, D. (2006). In touch with intangibles. Workforce Management, 85, 38-41.

Ulrich, D., \& Smallwood, N. (2005). HR's new ROI: Return on intangibles. Human Resource Management Journal, 44, 137-142.

Umiker, W. (1999). Principles of workforce stability. The Health Care Manager, 18, 58-64.

Van Marrewijk, M., \& Timmers, J. (2003). Human capital management: New possibilities in people management. Journal of Business Ethics, 44, 171-184.
Vincola, A., \& Mobley, N. (1998). Performance management through a work/life lens. HR Focus, 75, 9-10.

Walsh, J. P., Meyer, A. D., \& Schoonhoven, C. B. (2006). A future for organization theory: Living in and living with changing organizations. Organization Science, 17, 657-671.

Watts, T. (2000). The intangible dream. Business Review Weekly, December 1, 124.

Weiss, M. (1998). Intellectual capital: Valuable assets in banking. Future Banking, 2, 67.

Wiarda, E. A., \& Luria, D. D. (1998). The best-practice company and other benchmarking myths. Quality Progress, 31, 91-95.

Wintermantel, R. E., \& Mattimore, K. L. (1997). In the changing world of human resources: Matching measures to mission. Human Resource Management Journal, 36, 337-342.

Youndt, M. A., \& Snell, S. A. (2004). Human resource configurations, intellectual capital, and organizational performance. Journal of Managerial Issues, 16, 337-360. 